\title{
UNIVERSITYOF
}

FORWARD

THINKING

WESTMINSTER用

WestminsterResearch

http://www.westminster.ac.uk/westminsterresearch

Achieving Good Dividends Through Brand Leadership

Illes, K. and Kirkup, M.

This is an accepted manuscript of a book chapter published by Routledge in Good Dividends: Responsible Leadership of Business Purpose on 21 Feb 2019. Available from the publisher at:

http://www.routledge.com/9781138103528

The WestminsterResearch online digital archive at the University of Westminster aims to make the research output of the University available to a wider audience. Copyright and Moral Rights remain with the authors and/or copyright owners.

Whilst further distribution of specific materials from within this archive is forbidden, you may freely distribute the URL of WestminsterResearch: ((http://westminsterresearch.wmin.ac.uk/).

In case of abuse or copyright appearing without permission e-mail repository@westminster.ac.uk 


\section{Achieving Good Dividends through Brand Leadership}

\section{Malcolm Kirkup and Katalin Illes}

It is 15 years since we both awoke to realise we were part of the problem and not the solution. As an MBA Director at a prestigious Business School, Malcolm was educating business leaders. He was well aware of the growing number of corporate scandals, the shameful environmental degradation, human rights abuses in supply chains and, in 2008, the financial crisis, and these were issues his MBA students' analysed in great depth. But was he changing mindsets and behaviours, and producing more 'responsible' business leaders? He wasn't convinced. His determined subsequent journey to take more direct action led him ultimately in 2010 to join Jean-Paul Jeanrenaud from WWF and Jonathan Gosling at the University of Exeter to create a very different kind of MBA - the One Planet MBA. This was a unique, uncompromising MBA: a focus on the stewardship of natural and social capital as a central responsibility of business, with students who were keen to fight for change. Over the same 15 years, Katalin was engaged with a number of academic institutions across Europe and Asia. She observed how the limitations of Western business education models were being magnified abroad and often causing more harm than good. Business courses were being delivered wholesale without any regard for cultural differences or in-depth understanding of the specific historic, social, economic or ecological conditions. Katalin became frustrated with the limitations. She sees the need to educate the whole person and to equip students not only with technical skills but also how to find individual purpose and become a force for good in the world. We have now joined forces at Westminster Business School in London, bringing our respective interests in marketing and leadership together. Hence our excitement when Steve invited us to present our thoughts on brand leadership.

Along our respective journeys towards understanding brand leadership, we became aware of a successful and inspirational business that walks the talk: a brand that lives and breathes the essence of 'doing good'. The case of Elvis \& Kresse now features regularly as an exemplar in our teaching. The business launched in 2005, directly in response to the founders' own 'moral outrage': discovering the vast scale of waste generated by our society and, more specifically, the quantity that ends its life buried in landfill or incinerated. The founders' mission? To build a business that rescues and transforms waste, that is financially sustainable and that also delivers a social purpose. The business began by recovering decommissioned fire hose from the London Fire Brigade, transforming the hose into affordable luxury fashion accessories, and donating $50 \%$ of her profits from the hose lines to the Fire Fighter's Charity. The business has grown steadily to become a powerful purpose-driven brand that generates exceptional good dividends. We were so inspired by the business that we approached Kresse Wesling, co-founder, to share her journey and experiences with us, and we are delighted that she has contributed her thoughts to support this book.

In this chapter, we seek to unpack the nature of a brand and to explore how a 'purpose-driven' brand offers the prospect of enhanced dividends. We highlight how a successful purpose-driven brand generates shared value, brand preference, enhanced reputation, lower costs and a compelling source of innovation, whilst also educating and leading behavior change among consumers and among businesses that seek to emulate good practice. We then explore the leadership challenges facing CMOs in building purpose-driven brands: the need for clarity, consistency, authenticity and transparency, and also the challenges of maintaining the conversation with consumers through all activities, including partnerships. We conclude with our reflections on the importance of personal leadership in building good dividends. Throughout the discussion, we introduce observations from Kresse Wesling who, in our view is a brand leader who lives and breathes the essence of 'doing good'.

Let's begin with the nature of a brand. A brand can be a product, a service, a person, a business or even a place that is identifiable and made distinctive by specific and unique attributes or value. In an increasingly busy, noisy and competitive market place, with so many choices available to consumers, it is important to be noticed and to stand out, and so ease of identification and distinctiveness are important. As Leslie de Chernatony argues, a successful brand is one that can sustain this distinctiveness and its special value over time and in the face of competing alternatives (de Chernatony, 2010). The more distinctive the better, especially if competitors cannot replicate the advantage, although the nature of the distinctiveness must be relevant, important and of value to the consumer or user. Distinctiveness is not static and it can change over time, either in response to competition, changes in consumer needs or a desire to communicate a clearer proposition.

A successful brand motivates consumers to want to reciprocate and exchange value. A brand has a set of 'assets' - the sources of influence of the brand - which can be both functional and emotional. Functional assets might include the physique of a product, its performance, its cost or consistency. Emotional assets are less tangible but, through experience or reputation, bring 'meaning' to the brand - for example, perceived reliability, responsiveness, competence, courtesy, credibility, security, empathy or trust. A strong brand will develop and nurture a set of compelling, consistent and deep meanings or associations for the brand, which are valued by consumers. This combination of assets, in turn, produces a range of benefits - some in the form of financial brand equity outcomes (and the 
prospect of healthy returns in the future) but others relate to the effects and influences on consumers and other stakeholders. Strong brands can generate psychological or behavioural impacts reassurance, continuity, consistency, safety, loyalty, trust and advocacy. A brand is not just a projection to the external world, consumers and competitors. A strong brand also plays an important role in connecting an organization emotionally to its employees, suppliers and other stakeholders. It offers a positive association to customers. The choices that we make, the brands that we buy, or avoid, reveal many of our values, personal preferences and how we are in the world.

\section{So how does a purpose-driven brand offer the prospect of enhanced dividends?}

Sustainably-focused businesses seek to deliver 'shared value' for a range of stakeholders and not just shareholders. Porter and Kramer (2011) argue that businesses depend on the communities in which they exist and therefore need to focus on this connection in order to ensure long-term competitive success. Shared value can help secure long-term financial sustainability but also an increase in the overall value created by improving the economic and social conditions of the communities in which they operate. In the case of brands with an environmental and social mission, a clear dividend arises from being part of the solution. For Kresse, the motivation and goal for her business is focused emphatically on this contribution. Yes, the business needs to be financially sustainable, but she argues that the finance is primarily to provide the facility to deliver the higher purpose. Her enterprise metrics focus on the extent to which she is solving the problem she set out to address - initially, the 10-tonne-a year problem associated with fire hose waste - alongside the contribution she is able to pass on to the Fire Fighters Charity. Having largely accomplished the hose waste goal by 2010, the focus is now the 800,000 -tonne-a-year problem, redirecting leather-offcuts from landfill or incineration. Kresse noted that the growth metric, or their concept of ambition, is aligned with waste rather than profit. "I'm also motivated by whether or not we and our employees are happy, challenged and fulfilled. Whether we can sleep at night. On that, we do."

From a financial perspective, a good brand which is deeply meaningful offers the potential to win consumer preference against competing alternatives. In 2015, the Nielsen Global Corporate Sustainability Report indicated that $66 \%$ of consumers, and $73 \%$ of millennials, were willing to pay more for products sold by purpose-driven brands (Nielsen, 2015). For some consumers, strong brands create symbolic connections between goods and identities, and the purchase of a congruent brand may reinforce their self-identity and the coherency of their sense of self. This can be particularly the case with purpose-driven brands. Furthermore, consumers with similar identities form groups and communities. Brand consumption can provide symbolic and conspicuous information about which groups and communities we associate with, and can therefore enhance a sense of belonging. Consumers do not just 'buy' value in a transaction: they 'create' value from, and for, a product/service while using it. Kresse noted the particular emotional connection that attracts consumers to the E\&K brand. "Many of our customers save up to buy our bag because it reflects their values and they want to wear their heart on their sleeves. When people talk about statement handbags ... well, our bags make a different statement. Some buy for gifts ... and that's because you are giving more than a thing. You're giving recycling and you're giving 'giving'." The strong narrative behind the brand - both the environmental and social narrative - encourages repeat purchases, an acceptance of the premium price position and, importantly, active support from customers and an on-going 'conversation' both literally (via the web live chat and visits to the company's workshop) and metaphorically. But it is the brand advocacy that brings particular saliency dividends. Elvis \& Kresse customers are keen to demonstrate their support through telling the story behind the product and the enterprise. A good brand can be a powerful educator. It can make customers think beyond short term, personal gratification and consider the long term impact of their choices. By spending money on products that do not only serve a utilitarian purpose one moves beyond the 'disposable' mentality of consumption, contributes to the reduction of waste and makes vital steps towards a more responsible way of living. Customer satisfaction is multiplied by the emotional and psychological rewards of the act. By spending money wisely one moves from being a passive consumer to be an active participant of the change that is so badly needed in the world.

Doing good can also provide dividends through the improvement of an enterprise's reputation among external stakeholders. It can enhance credit-worthiness among investors and banks. A company's environmental and social performance can be a strong indicator of corporate adaptability, the durability of the company's competitive advantage and the quality of its leadership. Reputation is built on trust. It is a powerful yet fragile construct that needs continuous nurturing, reinforcement and protection. Leaders have a great responsibility to act as stewards, to protect the core values of the brand and actively seek opportunities to authentically enhance product qualities, communicate the advantages of the brand and work in close partnership with the business environment and society to maximize the positive impact of the brand. A good brand always represents more than the achievements of individual leaders. It is important to serve, first, the long-term interests of the brand rather than the short-term interest of key position holders in the organization. Brand reputation is a collective achievement and when a brand's reputation is tarnished the responsibilities also stay in the community. 
A purpose-driven brand can also save costs through reducing business risks: a more responsible approach and enhanced compliance can reduce the risk of litigation, the cost of accidents and reputational damage. Strong community relations can help preserve a company's social license to operate: ensuring uninterrupted operations, consistent access to raw materials and less resistance when entering new markets. On this latter point, a strong, trusted brand allows for brand extensions allowing the organisation to gain faster acceptance when launching new products or services and reducing the communication costs, if well known.

Kresse identified a further, significantly positive, dividend arising from her brand proposition: the opportunity to use the brand's credibility to educate and encourage changes in consumer behaviour. Consumers 'learn' from brands - through classical conditioning (conditioned product/service associations with the brand), instrumental learning (positive or negative reinforcement associated with good or bad deeds) and cognitive learning (through observation). Regular customers, and those with an emotional connection to the brand, can be highly effective advocates of the mission too. The interest that Kresse has successfully cultivated through her marketing and her presence in the media has also provided the opportunity to educate scores of young people. Not to build awareness of the 'product' but to build understanding of the environmental challenges of waste and landfill and to awaken a new generation of warriors. In the early years of the business, Kresse was invited by the Cabinet Office to be a Social Enterprise Ambassador in the UK: to visit Schools and Colleges, meet journalists and to present at countless functions. She made the most of the platform to educate a considerable audience. In her view, if you don't reach people you can't communicate: "I feel an obligation to show people there is a different way. And I'm proud of what we have achieved .... So I do feel like it allows me to be bold and to make statements and ask questions and to prod and push things a little bit further down the road in the direction of something better. I can only do that because running Elvis \& Kresse gives me that permission." While Kresse modestly claims she is "not yet a leader", her influence in the sustainable fashion and repurposing sector has been significant. Since 2005 her business model for affordable but luxury sustainable fashion has been emulated by numerous start-ups and also by some corporates: "The industry is coming to meet us, where we are, and conscious consumption is well on the rise". Rewarded in 2013 with an MBE, Kresse has inspired a movement which collectively produces significant good dividends.

Good dividends also arise through an enhanced connection with employees and other stakeholders. Companies with a purpose-driven agenda are better able to attract the best and brightest recruits. A strong brand - with a positive organizational culture and values - will motivate employees and build trust and faith in the organization. Knowing what the brand stands for can provide clarity for employees and help them embody and authentically deliver a consistent experience to customers. With the right motivation and incentives, employees can also be a valuable source of innovation with a vested interest in success. As with the external projection of a brand, internal dividends can therefore also arise from a strong brand: employee commitment, responsiveness, enthusiasm, higher productivity, loyalty and reduced staff turnover (Interbrand, 2018).

Any enterprise wishing to preserve long-term survival in any market needs to be active with innovation. If the business mission is authentically motivated to solving environmental and social problems, then these problems of themselves will drive creative innovation and the results will be a perpetuation of good dividends. Kresse argues that, for purpose-driven brands, innovation is easy: "We are not doing innovation in a crazy wide-open scenario. We're literally looking at a problem and it's a great way to focus the mind. We are looking at waste materials and thinking - what is it? What is it good for? What is its future? How can we extend its life and its value for good."

John Bessant, a colleague at Exeter on the One Planet MBA, identified four dimensions of innovation which should come naturally to a purpose-driven brand. Process innovation comes from a change in the way products and services are delivered. Production processes can be changed to reduce the use of chemicals, increase the durability of a product, or reduce energy, water and raw materials. Levi's concept of 'water-less' jeans demonstrates a high profile attempt to significantly reduce water-use in the manufacturing process. Product innovation comes when an enterprise changes the type of products and services offered. New products can be introduced to extend the life of a product or to facilitate their re-cycling. Global brands such as H\&M, Levi, Marks \& Spencer and Zara have introduced ranges that incorporate environment-friendly raw materials such as organic cotton, Tencel and recycled polyester. Position innovation arises when there are changes to the context in which products are framed and communicated. Over the last decade many global brands have sought to instill sustainability within their brand proposition. Paradigm innovation involves changes in the underlying mental models that shape what an organization does. Elvis \& Kresse is a good example of a business repurposing waste, and another new business model is emerging for traditional manufacturers. Paradigm innovation is also possible in the service sector. 'Forma Futura' for example is an independent Swiss asset management company. They invest responsibly in listed companies. Client funds are invested in a manner that ensures they increase the sustainable quality of life, and at the same time, achieve a fair market return. Linked with Chapter 8 in this volume, Desso, a Dutch manufacturer of carpet tiles, is introducing 'cradle-to-cradle' systems. The business model innovation is the ambition to 
move from an existing take-back and recycling system to a 'product-service system'. Rather than assuming customers will continue to buy, own and dispose of carpets, products could be reconceived as services that customers lease for a given period. This saves costs on materials, keeps harmful products out of the waste stream and builds relationships between supplier and customer.

\section{So what are the leadership challenges for building a strong purpose-driven brand?}

A brand which seeks to be distinctive and valued requires a clarity of purpose and a compelling narrative. Kresse has a strikingly simple and clear mantra, which represents the company's DNA and its brand values: reclaim, transform and donate: "We've had 13 years to nail it down...it's a compelling driving force and it informs everything we do." The products are all made from reclaimed materials parachute silk, auction banners, sail cloth, office furniture textiles, canvass printing blankets, leather off-cuts, jute and hessian coffee bags, tea sacks and shoe boxes. "If we started to make our products, with brand new materials, it would be over. And I've seen other companies do this. They start with an environmental story, then want to grow quickly and they lose it. That would be a red line for us. If pure growth was dictating those kinds of actions, we just wouldn't pursue it." There is also clarity in design. Whereas product design in a traditional company would start with an idea, for Elvis \& Kresse, design begins with a problem. It is the material and the scale of the problem which dictate what they will make and how they will make it: "In the case of the hose, we scrubbed away the soot and grease that builds up after 25 years of active duty and discovered a truly remarkable textile. We wanted to honour this tough, life-saving material." The brand values demand that design is classic and timeless and that products should be made to last as long as the materials they reclaim. There is no ostentation and no desire to make pieces that only last one season. Products are unique, hand-made and based on quality craftsmanship. The transformation process emulates Kintsugi, the Japanese art of repairing broken pottery with lacquer mixed with gold, silver or platinum, where breakage and repair becomes part of the history of an object. The refurbished pieces are worth significantly more than their new, undamaged counterparts. In Kresse's words: "It would never be enough to give an old fire hose a somewhat useful life: we must transform it, make it desirable or useful in and of itself." The clarity of purpose for the enterprise is also reinforced through certification as a BCorp, guiding and reminding the organisation of the essential values for a good dividend business. In an indirect way Elvis \& Kresse challenges the disposable mentality of consumerism underpinned by short term orientation. If everything is continuously replaced then nothing is really valued. In Chapter 12 Randall Zindler picks up on the leadership issues of governance and explores in detail the value to be derived from BCorps as a vehicle for helping to realise the good dividends.

A challenge for any brand is to ensure that its values are consistent and reflected in every aspect of its operation. For sustainable brands this is particularly important. Seeking to contribute to an environmental cause in one part of the business, whilst burning-up energy in another, will soon challenge the brands authenticity. Kresse is emphatic about this, not least because of the scrutiny that ethical brands are subjected to. The same brand values 'reclaim and transform' inform the packaging and communication materials. The labels, the stickers, the mail pouches and the foam padding are all reclaimed wastes. Until recently, the company had not used leaflets as they were unsure how to produce them in a way consistent with their values. Kresse now rescues tea sacks, cuts them to size and prints in an ecologically-friendly way: "I prefer to wait until we can do something right. I don't wish to compromise."

For a purpose-driven brand, strong values must also be consistent in the way employees are recruited, managed and nurtured. Kresse is particularly proud of the contribution the enterprise is making socially through employment. In 2007 they embarked on a collaboration with Remploy, a disability specialist that supports sustainable employment for the disadvantaged. They also support apprenticeships to bring young and local people into the business: "It is consistent with our values in so many ways. With an apprenticeship you can rescue a human being by offering that work opportunity. We can transform young people's lives with a worthwhile role and with kindness and respect". The company hires skilled talent too, but only if they share, or can learn and adopt, the company's values. This is important to Kresse: "At one time our Employee Handbook was just one sentence - 'If you litter, you're fired'. It set the tone because we all take this business and our example very seriously." Consistent with their values, the company is also a living-wage employer. Kresse believes their approach brings commitment, enthusiasm and enhanced productivity.

Consistency in an organization's brand values can also extend to the design of the physical fabric of buildings and offices. We were struck by the approach taken by Kresse to their premises in Tonge, Kent. The building is entirely consistent with their guiding values of reclaim, transform and donate. They have rescued a derelict 200-year old water mill, restored the building to its former glory and, in Kresse's words, "given it a chance of life for another century". The donation value is reflected not only in recovering the building for future generations, but also in restoring the wildlife habitat in the grounds. The area was previously home to rare water voles, and Elvis and Kresse have used old trees and reconstructed the landscape to provide a protected environment to support the voles' growth. 
With a purpose-driven brand, authenticity is crucial. Consumers or employees pledging custom, loyalty and advocacy, will demand that the enterprise is truthful and authentic. Even the best advertising will not create something that is not there. Without authenticity, trust will not follow. Leslie de Chernatony refers to a brand as a 'promise' - an experience that must be delivered consistently and authentically over time - and a failed promise in any relationship will lead to loss of trust (de Chernatony, 2010). The Boston Consulting Group (2011) has highlighted enhanced brand reputation as a benefit of addressing sustainability. However, if sustainability credentials can build a company's image, those credentials can also be easily damaged. Companies that fail to live by a set of declared principles may get away with it for a while, but intense scrutiny and negative feedback from customers (facilitated by the instant nature of online communications between activists, bloggers and consumers) can bring a brand down. Unless reality matches rhetoric, making sustainability claims is a risky business. It must be authentic, credible and defendable.

For a purpose-driven brand, a key demonstration of authenticity is vested in the personal behaviour of managers and employees. Brands are delivered by people, and so the CMO leader, and indeed all directors and employees, should be a living manifestation of the brand values. We have, sadly, seen countless examples where the behaviour of executives has fallen short of appropriate standards, with significant implications for both the executive and the organisation's value. We personally remember two classic examples broadcast on TV - and now preserved forever on YouTube - which highlight the point. In 1991, the jokes by Gerald Ratner at the Institute of Directors Annual Convention, denigrating the poor quality of his products. And the statement in 2010 by BP CEO Tony Haywood, commenting, in the face of the worst oil spill in US history and the death of 11 workers, that he wanted "my life back" (Reuters, 2010). For a purpose-driven brand, consumers, employees, suppliers and investors look to the organisation's leaders to be exemplary and consistent brand ambassadors. Any opposing or inconsistent messages damage consumer faith and trust.

Related to authenticity is the increasing need for ethical brands to prove their credentials. Transparency is important to enable traceability. Individual transparency is closely connected with corporate transparency as they continuously reinforce each other. Without transparency, secrecy creeps in, followed by manipulation and game-playing and these lead to a toxic environment that can ruin brands and individual lives. The fashion sector is noted for its secrecy with IP and new designs and, in some cases, a desire to hide what might be happening in their complex supply chains. Consumers, however, often want to know how products get to market. Kresse believes passionately in transparency. "We are a $100 \%$ transparent brand. We are vertically integrated. We manufacture almost everything ourselves, so we know where it is from. We can't make the zippers, but we source from YKK and they are covered by ISO14001 and so on, so we can trace and track." The transparency extends further for customers. Elvis \& Kresse advertise an open invitation to customers and interested observers to "visit our home at Tonge Mill" to see how their products are made. They also offer an opportunity to engage in a handson immersion in the waste-to-product process: joining workshops where customers can design and make their own "Fire and Hide" clutch bag, as well as share an evening with the business owners. This level of openness does not only confirm transparency it makes the abstract ideas of 'sustainable brand, values, long term commitment to waste reduction' a lived, observable and co-created experience. It offers a powerful example that an alternative way of being, working and leading is possible and achievable. It also conveys a strong 'can do' attitude and inspires visitors to review their own practices and make more responsible choices.

A consumer's perception of a brand emerges from a holistic experience. First is the experience of the products, services and advertising messages that are laid out in front of them by brand owners.

Second is the lived experience of the brand: owning and using the product, listening to others about their experiences and engaging with the array of customer-company touch-points. Effectively, this holistic brand experience is a 'conversation' - an ever changing, continuous, literal and metaphorical dialogue between an organization and its customers. As such, a brand experience needs to be continuously curated, narrated and maintained. With purpose-driven brands, where consumers have a stronger emotional connection and often seek to become a part of a community, the scale and depth of the conversation can increase. Kresse enjoys the interactions and the rewards, but admits her greatest challenge along the way is the "relentless" need for engagement: "You can't stop for a minute, when you are dealing directly with customers. They expect availability and engagement all the time." Although the leader's visibility and continuous connection with existing and future customers is important, inviting willing customers to engage more actively and act as ambassadors for the brand can enhance the impact of the brand, creating a ripple effect in communities and transferring the philosophy of Kresse to a broader range of possible initiatives.

If organisations are authentic about their missions, and the goal beyond financial sustainability is to drive social and environmental change, then partnerships and collaborations are more likely to be entertained. In working with partners, a purpose-driven brand can acquire networks and resources to extend their capability and capacity to achieve impact and change on a broader scale. Elvis \& Kresse have recently announced a major partnership with the Burberry Foundation, a high-profile and major corporate actor in the global fashion business. Elvis \& Kresse had already embarked on its second 
mission to tackle the 800,000 tonnes of leather waste going to landfill, but the new partnership with Burberry is, according to Kresse, "designed to super-charge' the rescue mission". The Burberry Foundation has provided a grant to support Elvis \& Kresse's work and to transform at least 120 tonnes of leather off-cuts from the production of Burberry products into a new range of accessories and homeware. The partnership "aims to affect real change in the supply chain of the leather goods industry", provide apprenticeship and work experience opportunities for young people and reach thousands through public events, competitions and workshops (Elvis \& Kresse, 2018). For Burberry, the partnership supports its new Responsibility agenda, of which a key role is to invent new approaches to revaluing waste. Kresse has been cautious about joining partners in the past when they have challenged the values of the enterprise or when the motivations were for show rather than for real. A partnership has to be based on trust and similar values, otherwise consumers will see through it: "We evaluate all prospective partners. Like in a marriage: do I trust them? Do I trust their motivations? We need partners who understand us and understand that sharing is a good idea."

\section{Reflections on Brand Leadership}

Our expectations of brand leaders are changing. It is no longer enough to continuously increase shareholder value and financial dividends. Leaders are also expected to follow a higher purpose and engage the brand in deeply meaningful activities that bring good dividends to all stakeholders and contribute positively to pressing global issues. The socioeconomic, geopolitical and cultural-spiritual challenges of our time are interconnected (Guattari, 2000). The enormity of these challenges requires a review of how humans relate to themselves, to each other and to the environment in a more responsible way (Obolensky, 2010). To address these issues we need a fundamental change of perspective. "Not only do we have to change things, but we have to change the way we see things" (Brabandere, L. de 2005, p. xi). The power and responsibility of brand leaders are significant. Strong brands are, by definition, well known and they can significantly influence choices and behaviours. By expanding the values and visibility of the brand to pressing global issues they invite consumers to buy into and support the higher purpose behind products. As the case of Elvis \& Kresse illustrates, a purposedriven brand can educate consumers and organisations about collective and individual responsibilities for the planet and the legacy we leave for future generations.

Leaders need to have clarity about their personal values and purpose and fully and passionately commit to the needs and the potential good dividends of the brand. Without an authentic and virtuous character it is not possible to lead and ignite the creative passion and drive in others. Good brand leaders guard the values of the organization, support inclusivity, release the energy of people, enlarge the human and intellectual capital of employees, build a purpose driven community and educate consumers and customers. According to Laloux: "the level of consciousness of an organisation cannot exceed the level of consciousness of its leader" (Laloux, 2014: 239). Leaders project their views, values and beliefs onto an organisation. Consciously, and often subconsciously, they drive the organisation in the direction that is close to their personal views of the world. It is a great competitive advantage when the personal values and purpose of the leader are closely connected with the underlying values and purpose of the brand. When there is a good fit, the leader passionately serves the interests of the brand. He/she will become one with the brand and protects its reputation with his/her whole being. Elvis \& Kresse was built on the founders' passion for sustainability and waste reduction. This passion gave the leadership energy and made 'reclaim, transform, donate' not only the published but also the 'lived' values of the organization.

As business school academics, and educators of the world's future brand leaders, we feel there needs to be far greater emphasis on value rationality in the curricula and initiatives to develop the whole person. We believe that self-knowledge, personal values, opportunities for character formation, finding purpose and meaning and battling with real life ethical dilemmas should become integral to university courses and leadership development programmes. And reference to examples of brand leaders such as Elvis \& Kresse can only beneficially impact on individuals, behaviours, values and choices of future generations.

\section{References}

Bessant, J. and J. Tidd (2015) Innovation and Entrepreneurship, John Wiley and Sons.

Boston Consulting Group (2010), The 'Embracers' Seize Advantage, MIT Sloan Management Review Research Report Winter 2011, MIT.

Brabandere, L. de (2005), The Forgotten Half of Change - Achieving Greater Creativity through Changes in Perception, Dearborn Trade Publishing, Chicago, IL.

de Chernatony, L. (2010) From Brand Vision to Brand Evaluation, Oxford : Butterworth-Heinemann. 
Elvis \& Kresse (2018) The Burberry Foundation Partners with Elvis \& Kresse,

https://www.elvisandkresse.com/blogs/news/the-burberry-foundation-partners-with-elvis-kresse

Guattari, F. (2000), Three Ecologies, The Athlone Press, London and New Jersey.

Interbrand (2018), Best Global Brands 2017, https://www.interbrand.com/best-brands/best-globalbrands/2017/

Laloux, F. (2014) Reinventing Organisations, Nelson Parker

Nielsen Company (2015), The Sustainability Imperative: New Insights on Consumer Expectations, October.

Obolensky, N. (2010), Complex Adaptive Leadership, Gower Publishing Limited

Porter, M.E. and M.R. Kramer (2011) Creating Shared Value, Harvard Business Review 89, nos. 1-2 (January-February 2011): 62-77.

Reuters (2010), BP CEO Apologizes, https://www.reuters.com/article/us-oil-spill-bp-apology/bp-ceoapologizes-for-thoughtless-oil-spill-comment-idUSTRE6515NQ20100602, Environment, June 2nd, 2010 